This document was prepared in conjunction with work accomplished under Contract No. DE-AC09-96SR18500 with the U. S. Department of Energy.

\title{
DISCLAIMER
}

This report was prepared as an account of work sponsored by an agency of the United States Government. Neither the United States Government nor any agency thereof, nor any of their employees, nor any of their contractors, subcontractors or their employees, makes any warranty, express or implied, or assumes any legal liability or responsibility for the accuracy, completeness, or any third party's use or the results of such use of any information, apparatus, product, or process disclosed, or represents that its use would not infringe privately owned rights. Reference herein to any specific commercial product, process, or service by trade name, trademark, manufacturer, or otherwise, does not necessarily constitute or imply its endorsement, recommendation, or favoring by the United States Government or any agency thereof or its contractors or subcontractors. The views and opinions of authors expressed herein do not necessarily state or reflect those of the United States Government or any agency thereof. 
PVP2005-71033

\section{PERFORMANCE OF A DRUM TYPE PACKAGING WITH URETHANE FOAM OVERPACK SUBJECTED TO CRUSH AND OTHER REGULATORY TESTS}

\author{
Allen C. Smith \\ Savannah River National Laboratory \\ Westinghouse Savannah River Company \\ Aiken, South Carolina 29808 \\ (803) 725 2943, allen.smith@srs.gov \\ Paul S. Blanton \\ Savannah River National Laboratory \\ Westinghouse Savannah River Company \\ Aiken, South Carolina 29808 \\ (803) 725 3738, paul.blanton@srs.gov
}

\author{
Lawrence F. Gelder \\ Savannah River National Laboratory \\ Westinghouse Savannah River Company \\ Aiken, South Carolina 29808 \\ (803) 725 8703, lawrence.gelder@srs.gov \\ Rex N. Lutz \\ Savannah River National Laboratory \\ Westinghouse Savannah River Company \\ Aiken, South Carolina 29808 \\ (803) 725 3847, rex.lutz@srs.gov
}

\begin{abstract}
General Purpose Fissile Package (GPFP) prototypes of two configurations, 16 in. and $181 / 2$ in. diameter drum overpacks, were subjected to the free-drop, crush, puncture, and thermal Hypothetical Accident Condition (HAC) sequential tests for 10CFR71, Type B packagings. The tests demonstrated that the prototypes are very robust, easily withstanding the structural tests. The tests also confirmed that the urethane foam-filled overpack was able to withstand the thermal test.
\end{abstract}

\section{INTRODUCTION}

The GPFP packaging design is a proposed replacement for DOT Specification 6M Metal Packaging. The replacement packaging must be able to transport the same contents as the $6 \mathrm{M}$, meet the Type $\mathrm{B}$ performance requirements, and be economical to build and use. The GPFP must be able to withstand the Hypothetical Accident Condition (HAC) Crush Test for DOE missions. The Crush Test requirement presents a severe challenge to drum type packaging. Finite element modeling (FEM) indicated that the rigid urethane foam-filled overpack employed by the GPFP design would be able to withstand the Crush Test. In order to confirm the predictions of the finite element model, prototype packagings were fabricated and subjected to the HAC sequential performance tests, less the immersion test.

The ability of the foam-filled overpack to withstand the HAC Thermal Test requirement was less amenable to computer modeling and simulation than the structural tests, because of the complexity of modeling the thermal degradation process. Accordingly, a thermal test of the prototypes was also undertaken. The thermal test was performed as the final challenge in the sequential testing of the prototypes.

The GPFP containment vessel is identical to the 9975 secondary containment vessel, which has already demonstrated its ability to withstand the immersion test. Therefore, the immersion test was omitted from this test program.

\section{TEST PROGRAM}

Test Packagings

The GPFP prototypes were assembled from existing drums that were modified as needed to conform to the GPFP design, and containment vessels left over from earlier 9975 testing. The containment vessel liner and aluminum distribution plates were also fabricated at the Savannah River Site (SRS). The drum overpack and lid foaming operations were coordinated for SRS by the Kansas City Plant (KCP) and performed by General Plastics. Prototypes employing a 16 in. diameter drum and a standard 18 1/2 in. diameter drum, both 36 in. tall, were assembled at SRS. Foam densities of 16, 20 and $24 \mathrm{lb} / \mathrm{ft}^{3}$ were employed in the $181 / 2$ in. diameter overpacks, and 20 and 24 $\mathrm{lb} / \mathrm{ft}^{3}$ foam in the $16 \mathrm{in}$. diameter overpacks. The components of the GPFP are illustrated in Figure 1. 


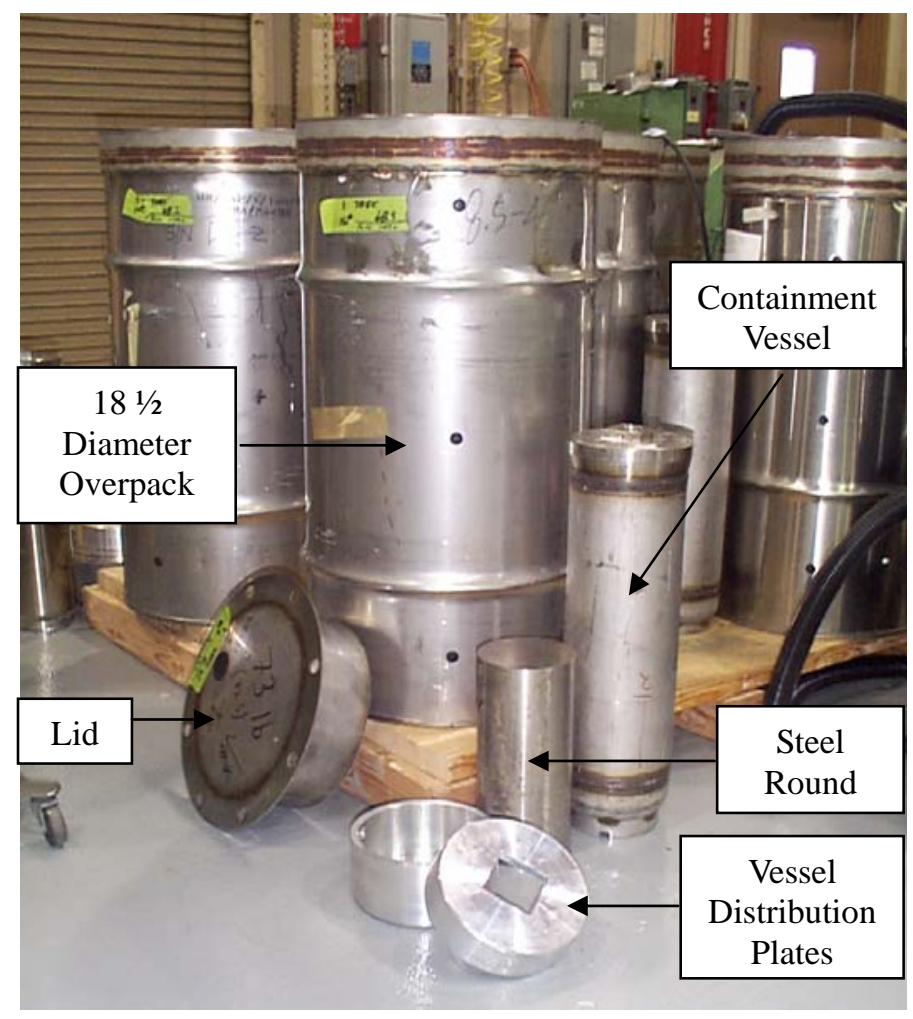

Figure 1 -- GPFP Components

\section{$\underline{\text { Facilities }}$}

All of the packaging performance tests were conducted at SRS. The Drop and Puncture Tests were performed using the Savannah River National Laboratory (SRNL) drop test facility, used for previous testing of the 9975 and other packagings. Because of the rebounding of the crush plate observed during previous crush tests, the SRNL drop test facility could not be used for the crush testing. Consequently, a crush test base plate, 48 inches square by 3-in thick, was fabricated at SRS and was grouted and bolted to a large concrete footer embedded in the floor slab of a dismantled shop building. Concrete traffic barrier segments were installed at the crush test site to protect equipment, such as the mobile crane and video cameras, from wayward bounces of the crush plate. A circular electromagnet rigged to a crane was used to lift and release the crush test plate.

A general purpose industrial heat treatment furnace, previously employed for preliminary thermal tests on the 5320 packaging, was used for thermal testing of the GPFP prototypes. A test stand to support the packagings in the furnace was constructed from angle iron. The test stand held the packaging horizontally and as near the center of the furnace as adequate clearance for the handling boom allowed. The test stand also served as a calorimeter to confirm the thermal radiation field in the furnace met the packaging thermal test requirement. The furnace was heated to $1,700 \mathrm{~F}$ and held at that temperature for three hours to attain steady state conditions in the furnace walls, and thereby minimize the effect of opening the door and inserting the packaging on the radiation environment in the furnace. Upon opening the door to insert the packagings, it was noted that the color temperature of the stand closely matched the furnace refractory wall, in every case. This observation, combined with the furnace thermocouple readings, confirms that the radiation environment in the furnace was consistent with the test requirements.

Following the completion of each performance test, Digital Radiographic (DR) imaging of each packaging was performed to evaluate the effects of the test on the internal structure of the packaging. Each packaging was radiographed prior to testing to establish a baseline for damage assessments.

\section{Test Plan}

A test plan was approved by the customer, KCP, and performed by the Savannah River Packaging Technology Group (SRPT). The tests were planned to evaluate the performance of the various foam-filled overpack configurations with respect to the regulatory crush and thermal tests. In order to compare the performance of the foam and effect of overpack diameter, the horizontal tests were conducted with $20 \mathrm{lb} / \mathrm{ft}^{3}$ foam packagings, using one 16 in. and one 18 1/2 in. diameter overpack. The axial tests were conducted with $24 \mathrm{lb} / \mathrm{ft}^{3}$ foam packagings, using one 16 in. and one 18 1/2 in. diameter. The lower density foam was selected for the horizontal case because the lower density foam has lower strength and this orientation was most challenging to the packaging in the crush test.

The $16 \mathrm{lb} / \mathrm{ft}^{3}$ foam was expected to have the lowest strength. The packaging with the $16 \mathrm{lb} / \mathrm{ft}^{3}$ foam was subjected to the Center of Gravity Over Corner (CGOC) drop and crush orientation, which was expected to produce the most extensive deformation of the overpack, and consequently be most challenging to the overpack closure. The drop and crush test orientations for the respective packagings are summarized in Table 1.

\begin{tabular}{|c|c|c|c|}
\hline \multicolumn{4}{|c|}{ Table 1 -- GPFP Drop and Crush Test Plan } \\
\hline $\begin{array}{c}\text { Packaging } \\
\text { Identification No. }\end{array}$ & $\begin{array}{c}\text { Drum } \\
\text { Diameter } \\
\text { (in) }\end{array}$ & $\begin{array}{c}\text { Foam } \\
\text { Density } \\
\left(\mathrm{lb} / \mathrm{ft}^{3}\right)\end{array}$ & $\begin{array}{c}\text { Test } \\
\text { Orientation }\end{array}$ \\
\hline DP-1 & $18^{1 / 2}$ & 16 & CGOC \\
\hline DP-2 & $18^{1 / 2}$ & 24 & Axial \\
\hline DP-3 & $18^{1 / 1} 2$ & 20 & Horizontal \\
\hline DP-5 & 16 & 24 & Axial \\
\hline DP-6 & 16 & 20 & Horizontal \\
\hline
\end{tabular}

\section{TESTING}

The structural tests were performed in accordance with the SRPT drop test procedure. Prior to loading the containment 
vessels into the overpacks, the packagings were radiographed. Temperature indicating labels were installed on exterior and interior of the containment vessels (CV). The vessels were loaded with surrogate contents, $100 \mathrm{lb}$ of stainless steel, and leak tested before assembling them into the overpacks. The fully assembled packagings were then radiographed. Figure 2 is a pre-test composite image of DP-1.

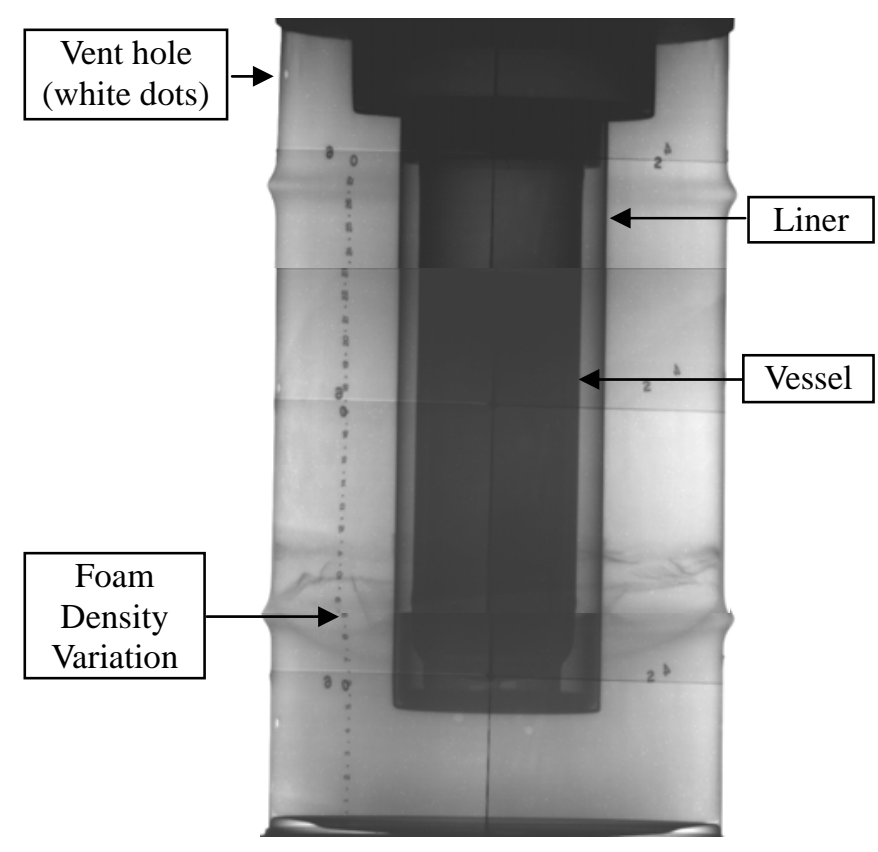

Figure 2 -- DP-1 Digital Image (composite)

The packagings were subjected to $4 \mathrm{ft}$ Normal Conditions of Transport (NCT) free drops prior to the $30 \mathrm{ft}$ HAC free drops. All of the NCT preconditioning drops were performed in the CGOC orientation. The NCT test setup is shown in Figure 3.

The packagings were oriented as listed in Table 1 for the $30 \mathrm{ft}$ Drop Tests. Following the drop tests, the packagings were radiographed. The packagings were next subjected to the Crush Test in accordance with the SRPT field procedure. The orientations of the packagings for the crush test were the same as the drop test, with the crush test plate targeted to strike the region of the packaging damaged by the drop test. Following the Crush Tests, the packagings were radiographed. The final phase of the structural test was the Puncture Test. These tests were performed in the drop test facility, with the puncture pin welded to the drop test pad. The target for the puncture pin strike was chosen to be the most damaging to the overpack. Following the Puncture Test, the packagings were again radiographed.

The thermal tests were conducted in accordance with the SRPT thermal test field procedure. This procedure is based on guidance given in the ASTM Thermal Test Standard E2230-02. The initial tests were performed using the "steady state" method, described in the Standard, in which the 30 minute test exposure begins when the drum surface temperature attains 800C. Experience showed that this method resulted in an overly severe test, since the urethane foam in contact with the drum surface absorbed heat and significantly delayed attaining 800C. Accordingly, the last tests were conducted using the test stand structure as a calorimeter. The thermocouples mounted on the test stand provided indication that the radiation environment in the furnace satisfied the HAC test requirement for the start of the tests. After the 30 minute thermal exposure, the packagings were removed and allowed to cool. Following the thermal tests, the packagings were radiographed.

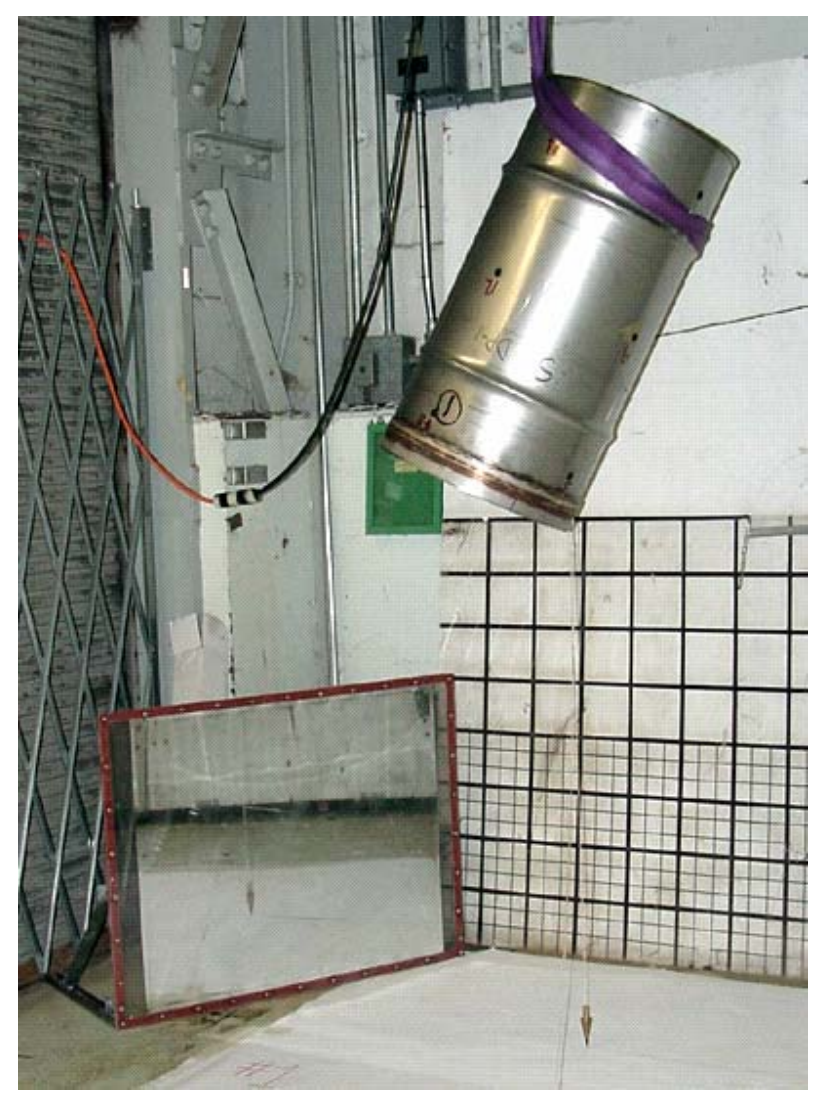

Figure 3 -- DP-1 NCT Test Setup (typical)

The packagings were then disassembled and the containment vessels removed to record temperature label data and for leak testing. The temperature labels on the exterior of the CVs were recorded and the CVs were leak tested. Finally, the CVs were opened, the steel rounds used as surrogate contents were removed, and the temperature labels on the interior of the CVs were recorded. 


\section{RESULTS}

Drop Test

The drop tests confirmed the ability of the urethane foamfilled overpack to withstand the drop and crush test and provide adequate protection for the containment vessels. The GPFP displayed less deformation in the CGOC tests than packagings with fiberboard insulation, such as the $6 \mathrm{M}$ or 9975 . The response of the GPFP to the impact was more energetic and elastic than that of the fiberboard packaging.

In the axial drop tests, the packagings were dropped top down. Because of the raised rim employed on the GPFP, the lid of the packaging was pushed (heaved) outward about $3 / 4$ in. by the liner contents as shown in Figure 4. Deformation of the overpack was minor. As in the CGOC case, the response of the packaging to the drop and crush tests were more energetic than that of fiberboard packagings for the same test.

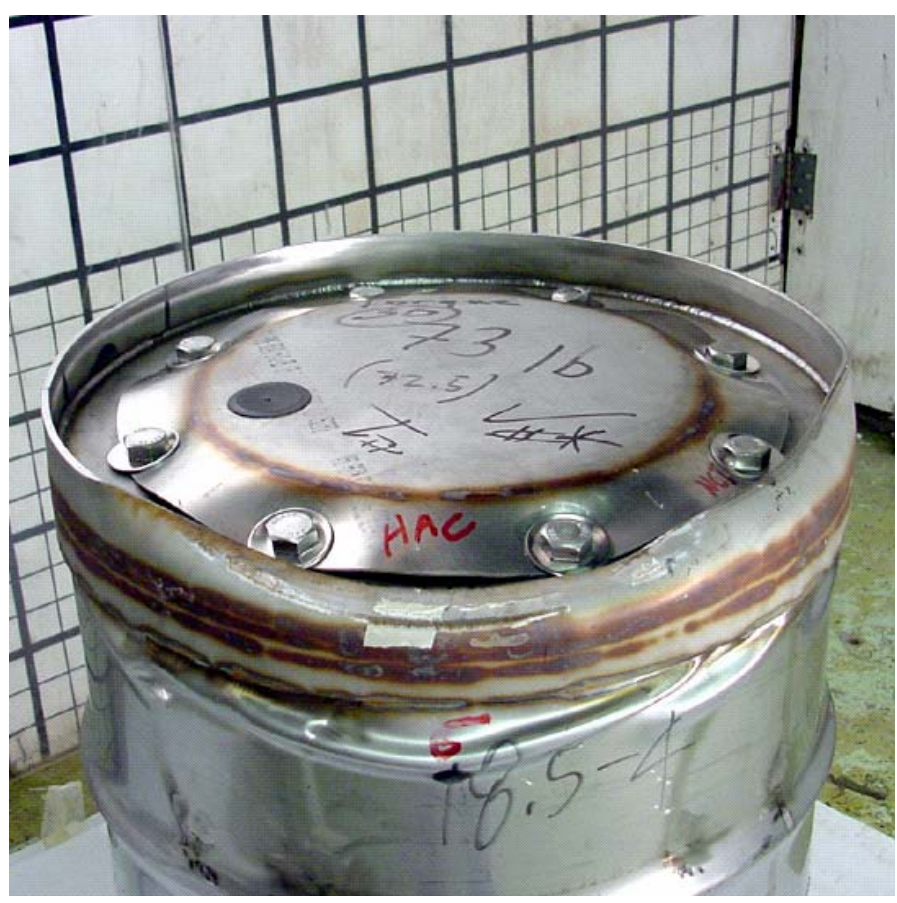

Figure 4 -- DP-1 Lid Heave and Crush Damage

The horizontal drop resulted in flattening of the side of the overpack. The extent of the flattening was less that that of typical fiberboard packagings under the same conditions. As in the CGOC and axial drop, the response of the GPFP was more energetic than that of fiberboard packagings for the same test.

\section{Crush Test}

The Crush Test in the CGOC orientation resulted in crushing of the opposite corner of the overpack and minor additional crushing of the previously damaged area, where the plate struck the overpack. See Figure 5.

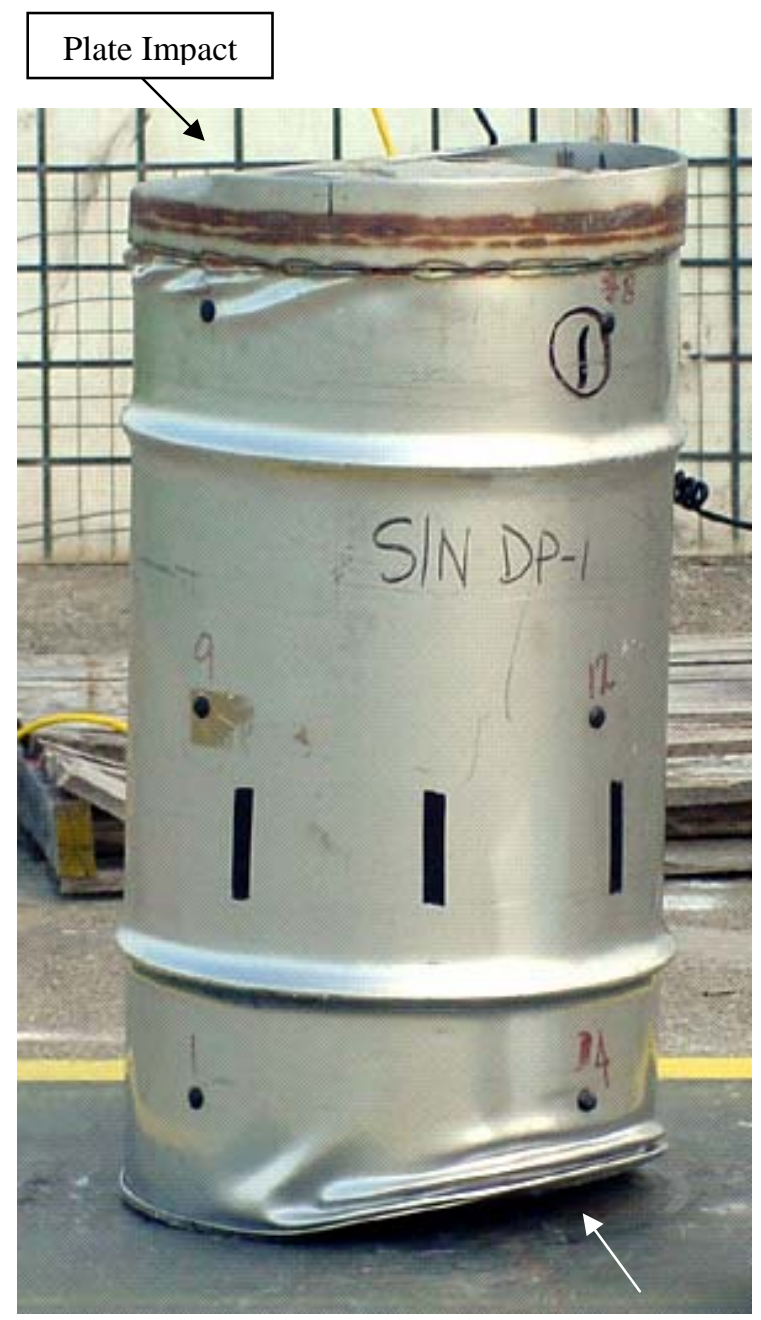

Figure 5 -- DP-1 Crush Test Deformation

The Crush Tests for the axial orientation resulted in deformation of the rolled chime at the bottom of the overpack and minor additional deformation of the drum sides in the previously damaged areas.

The Crush Test for the horizontal orientation resulted in flattening of the overpack on the side opposite the previously damaged area and ripples across the top and bottom. The extent of the flattening was comparable to that of the previous drop tests. See Figure 6 . In the horizontal case, the deformation was much less severe than that reported for fiberboard drum type packagings. The Crush Test results confirmed that the urethane foam-filled overpack was able to adequately protect the containment vessel from deformation during such an event. 

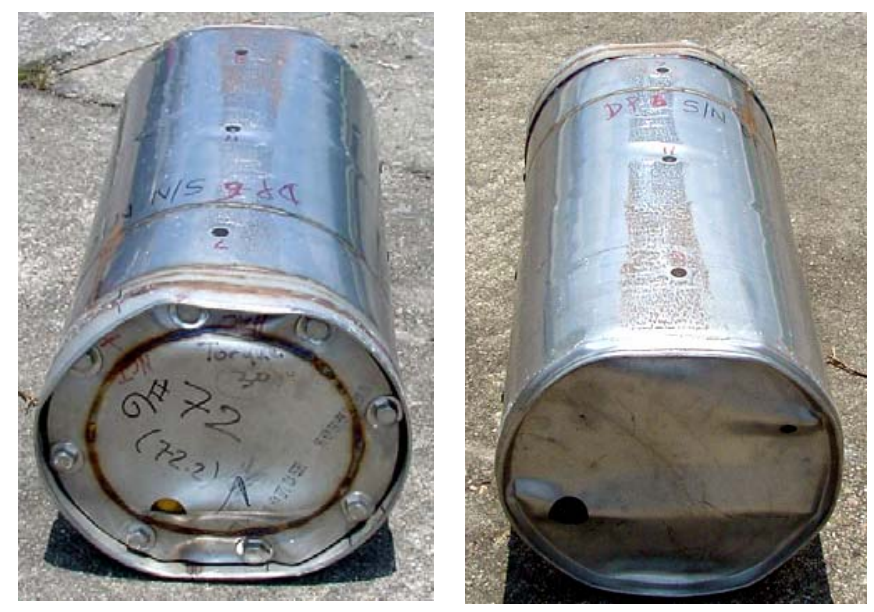

Figure 6 -- DP-6 Lid and Bottom Crush Deformation

\section{Puncture Test}

The Puncture Test is a minor challenge for drum type packagings. In each case, the damage to the prototypes by the 40 in. drop onto the puncture pin was superficial. The DP-5 overpack suffered a minor tear from the Crush Test, caused by a secondary hit by the corner of the crush plate, as shown in Figure 7. This area was targeted for the pin strike; however, the pin strike did not increase the size of the tear.

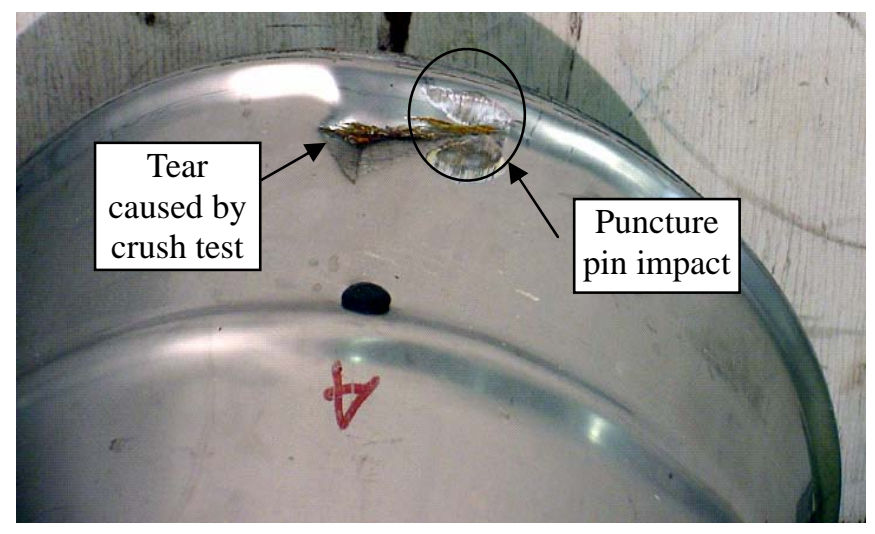

Figure 7 -- DP-5 Puncture Pin Impression

\section{Thermal Test}

A short time after insertion of each packaging into the furnace, a large volume of dark smoke began to escape around the door of the furnace. The smoke and gas burned as it exited from the crack around the door. The urethane foam used in the prototypes intumesces $226-248 \%$ as it undergoes thermal decomposition. That is, it forms a large amount of low density, ash-like decomposition product and gases. These components burn when exposed to air. The decomposition product flowed from every opening in the drum overpack, in the form of thick snake-like limbs and formed mounds on the floor of the furnace around the overpack. This flowing decomposition product inside the overpack absorbs heat from the overpack outer surface, preventing the surface from reaching $800 \mathrm{C}$ used as a criterion in the "steady state" test method. The time from packaging insertion in the furnace to start of the test interval (i.e., delta) is shown in Table 2.

\begin{tabular}{|c|c|c|c|c|c|c|}
\hline \multicolumn{7}{|c|}{ Table 2 -- Thermal Test Summary } \\
\hline $\begin{array}{c}\text { Test } \\
\text { Order }\end{array}$ & $\begin{array}{c}\text { Insert } \\
\text { to test } \\
\text { start } \\
\text { delta } \\
\text { (min) }\end{array}$ & $\begin{array}{c}\text { Test } \\
\text { Method }\end{array}$ & $\begin{array}{c}\text { Top } \\
\text { TC } \\
30\end{array}$ & $\begin{array}{c}\text { Bot. } \\
\text { TC } \\
\text { 30 } \\
\text { Min } \\
\text { Avg. } \\
\text { Temp } \\
\text { (C) }\end{array}$ & $\begin{array}{c}\text { Test } \\
\text { Stand } \\
\text { Avg. } \\
\text { Temp } \\
\text { (C) } \\
\text { TC 30 } \\
\text { Min } \\
\text { Avg. } \\
\text { Temp } \\
\text { (C) }\end{array}$ & $\begin{array}{c}\text { Test } \\
\text { Stand } \\
\text { Rear } \\
\text { TC 30 } \\
\text { Min } \\
\text { Avg. } \\
\text { Temp } \\
\text { (C) }\end{array}$ \\
\hline DP-1 & 16 & $\begin{array}{c}\text { Steady } \\
\text { State }\end{array}$ & 850 & 810 & 729 & N/A \\
\hline DP-6 & 15 & $\begin{array}{c}\text { Steady } \\
\text { State }\end{array}$ & 802 & 781 & 790 & 756 \\
\hline DP-5 & 21 & $\begin{array}{c}\text { Steady } \\
\text { State }\end{array}$ & 822 & 778 & 864 & 863 \\
\hline DP-3 & 9 & Calorimeter & 812 & 757 & 765 & 776 \\
\hline DP-2 & 8 & Calorimeter & 823 & 792 & 788 & 812 \\
\hline
\end{tabular}

The intumescing foam and decomposition gases also pressurized the interior of the drum; consequently, the bottoms of the of the prototype overpacks were typically bulged and packaging DP-2, which had experience damage to the chime, opened over an arc of approximately 100 degrees along the bottom chime. The last two thermal tests were performed using the stand temperature as the basis to start the test. As the packagings were withdrawn from the furnace, burning jets of gaseous decomposition products streamed from the openings in the overpack, along with molten plastic and the low density ash-like decomposition product. See Figure 8 for packaging insertion and view of the test stand, Figure 9 for removal of packaging from the furnace, and Figure 10 for DP-2 damage from the test.

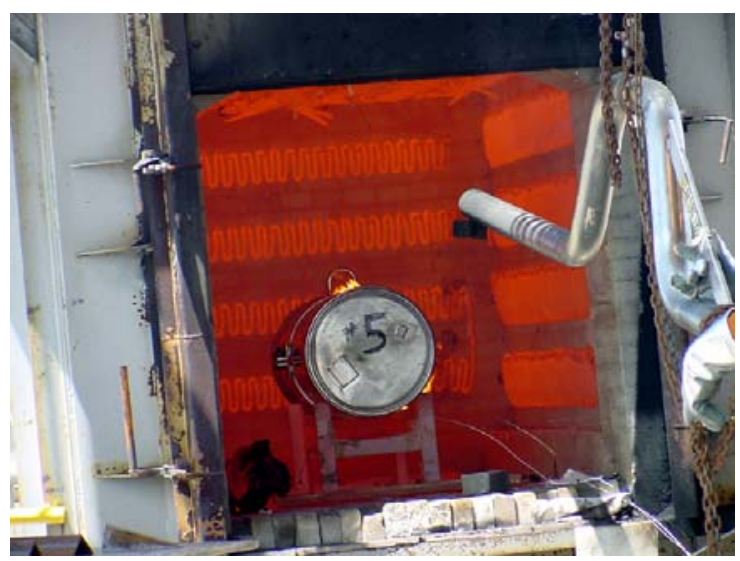

Figure 8 -- DP-5 Furnace Insertion 


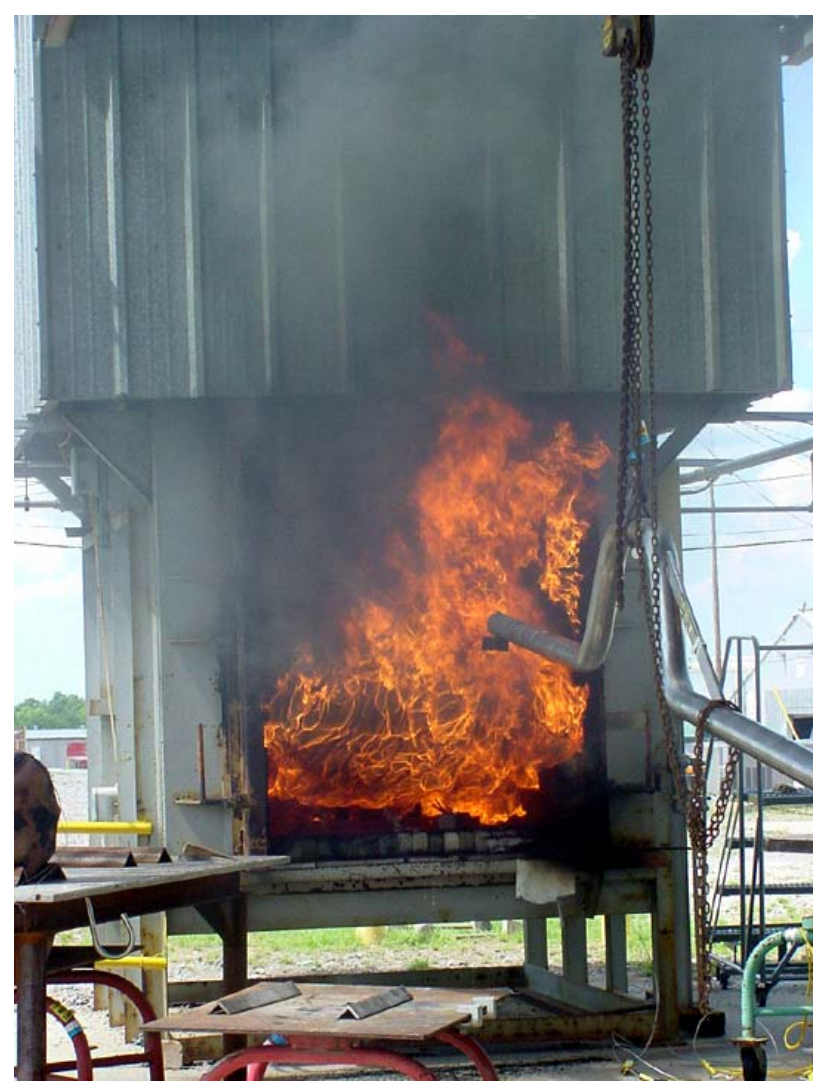

Figure 9 -- DP-5 Removal from Furnace

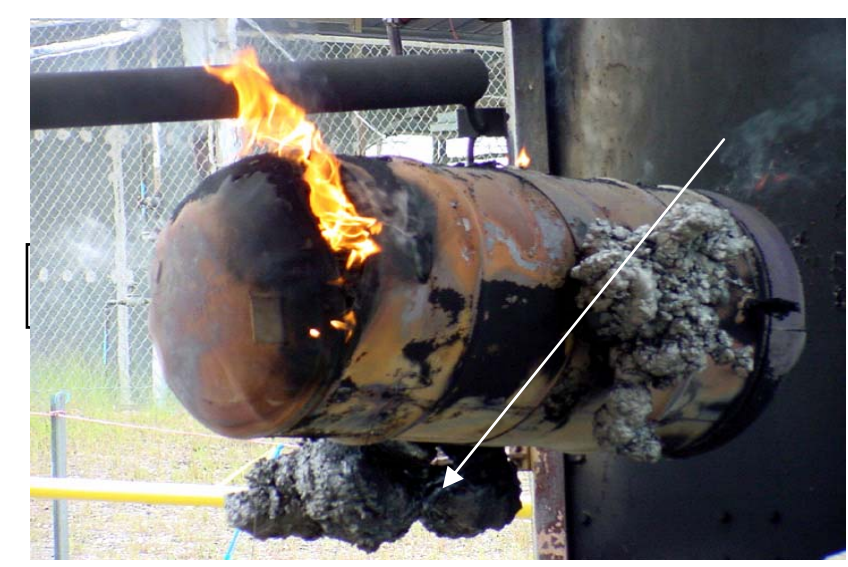

Figure 10 -- DP-2 Thermal Test Damage to Overpack and Thermal Decomposition Products

The overpacks were covered with a layer of soot, upon removal. After about 20 minutes, the flames self extinguished. The thermal test of the packagings all resulted in significant loss of mass of the urethane foam, in the course of the test, as expected. Post test examination of the CGOC and axial test packagings showed that a thick layer of undegraded foam remained around the inner liner. For the horizontal test packagings, the residual, undegraded layer of foam had a wide gap down each side, corresponding to the region of damage expected for a flattened thick-wall cylinder. In all cases, the remainder of the annulus between the liner and the overpack was filled with low density, ash-like decomposition product. The foam weight loss is summarized in Table 3 and visible in the radiograph image shown in Figure 11.

\begin{tabular}{|c|c|c|c|}
\hline \multicolumn{4}{|c|}{$\begin{array}{l}\text { Table } 3 \text { - Foam Weight Loss Summary Following Thermal } \\
\text { Testing }\end{array}$} \\
\hline Packaging & Initial (lb) & Final (lb) & Difference (lb) \\
\hline DP-1 & 338 & 288 & 50 \\
\hline DP-2 & 355 & 303 & 52 \\
\hline DP-3 & 350 & 301 & 49 \\
\hline DP-5 & 329 & 279 & 50 \\
\hline DP-6 & 315 & 271 & 44 \\
\hline
\end{tabular}

The temperature labels indicated that the peak temperature of the closure region of the containment vessels was approximately 340F.

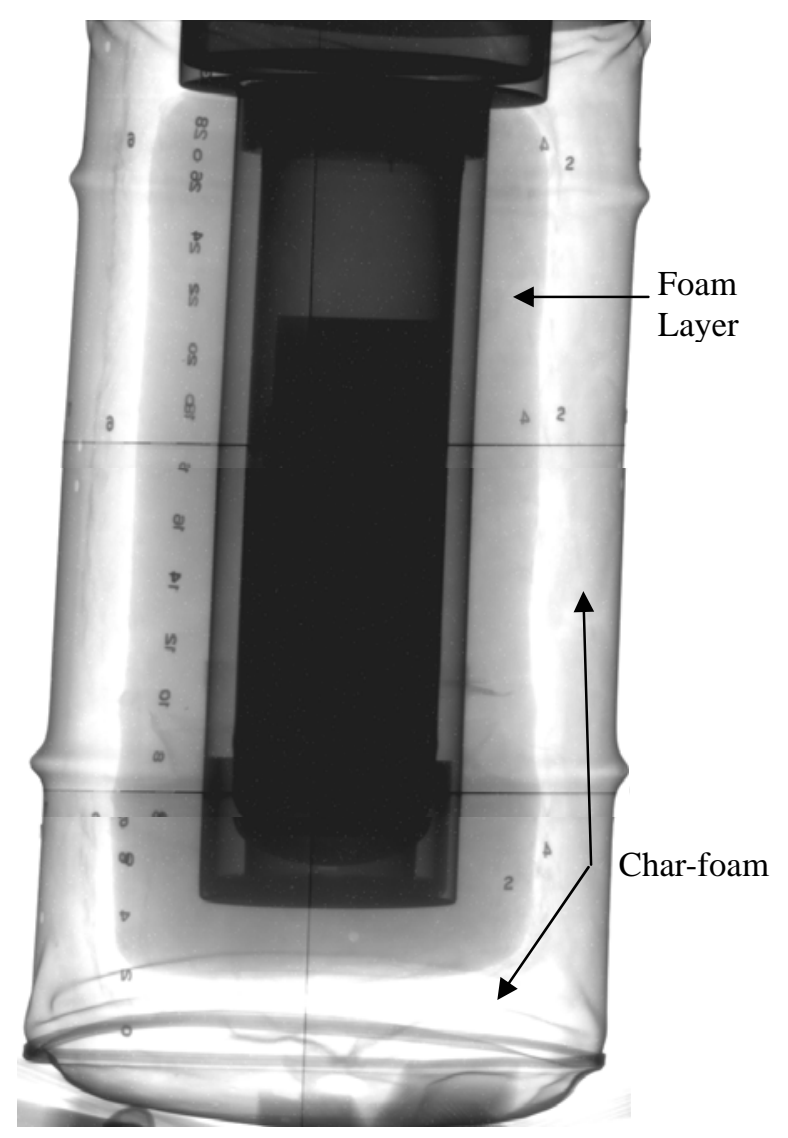

Figure 11 -- DP-1 Post Thermal Composite Image 


\section{Leak Test}

The post HAC leak tests were standard post-load leak tests performed using the same procedure as used in the pre-test leak test. The test is conducted at 150 psig for twenty minutes with a 1 psig pressure loss and $\pm 1 \mathrm{C}$ temperature change as acceptance criteria. DP-2 experienced a pressure drop of 1.4 psig, and so did not satisfy the 1 psig criterion. All other packagings met the criterion. The vessels were opened to record the temperature label data and remove the surrogate contents (steel rounds). Containment vessel DP-2 was reassembled and leak tested. The pressure drop was 0.6 psig, which meets the 1 psig criterion. Following removal of the surrogate contents, the O-rings from each vessel were removed, inspected, and found to be resilient and in apparent good condition. The post HAC leak test results are shown in Table 4.

A torque wrench was used to determine the break-away torque of the vessel lid during disassembly. The results are also given in Table 4.

\begin{tabular}{|c|c|c|c|c|c|}
\hline \multicolumn{7}{|c|}{ Table 4 -- Post HAC Leak Test Results } \\
\hline Packaging & $\begin{array}{c}\text { Initial } \\
\text { Pressure } \\
\text { (psig) }\end{array}$ & $\begin{array}{c}\text { Final } \\
\text { Pressure } \\
\text { (psig) }\end{array}$ & $\begin{array}{c}\text { Pressure } \\
\text { loss } \\
\text { (psig) }\end{array}$ & $\begin{array}{c}\text { Initial } \\
\text { Torque } \\
\text { (ft-lb) }\end{array}$ & $\begin{array}{c}\text { Breakaway } \\
\text { Torque } \\
\text { (ft-lb) }\end{array}$ \\
\hline DP-1 & 153.0 & 152.0 & 1.0 & 100 & 38 \\
\hline DP-2 & 152.2 & 150.8 & 1.4 & 100 & 42 \\
\hline DP-3 & 152.7 & 151.7 & 1.0 & 100 & 29 \\
\hline DP-5 & 153.1 & 152.4 & 0.7 & 100 & 28 \\
\hline DP-6 & 152.8 & 152.0 & 0.8 & 100 & 42 \\
\hline
\end{tabular}

\section{DISCUSSION}

The GPFP prototypes proved very robust in all HAC structural tests. With respect to the test objective, this testing confirmed that the rigid urethane foam-filled overpack was able to withstand the HAC Crush Test.

As was discussed above, the Thermal Testing methods were judged to be much more severe than a regulatory pool fire test, due to the higher temperatures of the furnace and the extended time before the packaging attained the $800 \mathrm{C}$ surface temperature required by the test method. Nevertheless, the temperature labels indicated that the O-rings remained within the service temperature range which is acceptable for short duration exposure. The foam acted as an ablative heat shield, with the decomposed material carrying away heat from the undecomposed foam surface. The gaseous decomposition products left a sooty deposit or tar-like residue on the vessel and overpack liner. The quantity of residue varied from packaging to packaging, depending on the nature of the structural damage.

The packagings which were horizontally crushed also experienced thermal degradation of the foam in the region along the mid plane parallel to the impact surfaces. This region is where a thick wall cylinder would fail under a diametral load. It is apparent that damage to the foam-filled overpack from the structural tests made these areas more vulnerable to thermal decomposition than cases where this structural damage did not occur. However, the decomposition product provided sufficient thermal insulation to the extent that the containment vessel temperature difference was insignificant.

\section{CONCLUSIONS AND RECOMMENDATIONS}

The foam-filled overpack design was able to withstand all structural HAC tests and provide adequate protection for the containment vessel.

The foam-filled overpack was able to provide adequate thermal protection for the containment vessel. Furthermore, the thermal tests indicate that a sufficient number of drum overpack vents is important to accommodate the intumescing foam and to avoid over pressurization and subsequent deformation of the overpack in a fire event. The margin of safety to avoid overheating of the containment vessel O-ring seals would be improved by reducing heat transfer into the packaging. This can be accomplished by reducing the thickness of the liner and replacing the aluminum distribution plates with a lower thermal conductivity material.

These performance tests confirm that the GPFP design is fundamentally sound and meets the free-drop, crush, puncture, and thermal test requirements for Type B packagings.

\section{REFERENCES}

1. General Purpose Fissile Package Prototype Test Plan, MTPL-G-00004, Rev 0, May 2004, Aiken, SC

2. Title 10, U. S. Code of Federal Regulations, Part 71.

3. Standard Practice for Thermal Qualification of Type B Packages for Radioactive Material, ASTM E 2230-02.

4. Drop Testing of Radioactive Material Packages, Procedure L9.5-9150, Revision 1, October 22, 2003, Savannah River National Laboratory, Aiken, SC

5. Crush Test of GPFP Prototype Units, EES Field Procedure FP-990, Rev. 0, August 2004, Savannah River National Laboratory, Aiken, SC.

6. Thermal Test of GPFP Prototype Units, EES Field Procedure FP-990, Rev. 0, August 2004, Savannah River National Laboratory, Aiken, SC.

7. Annual Leak Test for 9965, 9968, 9975, and DDF-1 Cone closure Containment Vessel, L9.4-8300, Rev 11, EESD/IES Procedures Manual L9.4, Savannah River National Laboratory, Aiken, SC

8. Proof/Leak Test Procedure, L9.4-8313, Rev 3, EESD/IES Procedures Manual L9.4, Savannah River National Laboratory, Aiken, SC 